\title{
The Phenotypes of Polycystic Ovary Syndrome Defined by the 1990 Diagnostic Criteria Are Associated with Higher Serum Vaspin Levels than the Phenotypes Introduced by the 2003 Criteria
}

\author{
Ekaterini Koiou $^{a} \quad K^{\prime}$ onstantinos Dinas ${ }^{a} \quad K^{\prime}$ onstantinos Tziomalos ${ }^{b} \quad$ Konstantinos Toulis $^{a}$ \\ Eleni A. Kandaraki ${ }^{a}$ Emmanuil Kalaitzakis $^{a} \quad$ Ilias Katsikis $^{a}$ Dimitrios Panidis $^{a}$ \\ a Division of Endocrinology and Human Reproduction, Second Department of Obstetrics and Gynecology, Hippokration Hospital, \\ ${ }^{b}$ First Propedeutic Department of Internal Medicine, AHEPA Hospital, Aristotle University of Thessaloniki, Thessaloniki, Greece
}

\section{Keywords}

Polycystic ovary syndrome .

Polycystic ovary syndrome phenotypes - Obesity . Insulin resistance . Vaspin

\section{Summary}

Objective: Patients with polycystic ovary syndrome (PCOS) diagnosed with the 1990 criteria (i.e. presence of oligo- and/or anovulation (ANOV) and hyperandrogenemia and/or hyperandrogenism (HA) with or without polycystic ovaries (PCO)) appear to have a more adverse metabolic profile than patients diagnosed with the additional criteria introduced in 2003 (i.e. presence of HA and PCO without ANOV and presence of ANOV and PCO without HA). Vaspin is a novel adipokine that appears to preserve insulin sensitivity. We aimed to assess serum vaspin levels in patients with different PCOS phenotypes. Methods: We studied 100 patients with PCOS diagnosed with the 1990 criteria (group I), 100 patients with PCOS diagnosed with the additional 2003 criteria (group II) and 50 healthy controls. Results: Serum vaspin levels were higher in groups I and II than in controls ( $p<$ 0.001 and $p=0.001$, respectively) and in group I when compared to group II $(p=0.045)$. In patients with PCOS, serum vaspin levels were independently correlated with BMI $(p<0.001)$ and the homeostasis model assessment of insulin resistance (HOMA-IR) $(p=0.002)$. Conclusions: PCOS is associated with elevated serum vaspin levels. This increase might represent a compensatory mechanism to preserve insulin sensitivity. Moreover, serum vaspin levels reflect the severity of PCOS and are significantly increased in its 'classical' phenotypes.

\section{Introduction}

Diagnostic criteria for the polycystic ovary syndrome (PCOS), as suggested in the Rotterdam conference sponsored by the European Society for Human Reproduction and Embryology and the American Society for Reproductive Medicine (ESHRE/ASRM) in 2003, include: i) oligo- and/or anovulation (ANOV), ii) hyperandrogenemia and/or hyperandrogenism (clinical signs of high androgen levels) (HA) and iii) polycystic ovaries. Diagnosis requires the presence of at least two of the three features after the exclusion of other androgen excess disorders $[1,2]$. Therefore, four different phenotypes of PCOS arise according to the combination of its three main manifestations (table 1).

Despite the recommended criteria, there is still controversy among the experts about the importance of each feature and the severity of the reproductive and metabolic dysfunction each phenotype implies [3, 4]. Thus, the phenotypic group with all three criteria is termed 'severe' [4] while, notably, the presence of both ANOV and HA, independent of polycystic ovaries, was required for the diagnosis of the syndrome before 2003 [5].

Obesity is present in varying degrees $(30-70 \%)$ in women with PCOS [6] and is usually of the central type [7]. Central obesity, being a prominent feature of the so-called metabolic syndrome, is directly linked to increased peripheral insulin resistance (IR) [8]. Furthermore, PCOS itself has been shown to confer a risk for IR, beyond that caused by obesity alone [9].

Visceral adipose tissue-derived serine protease inhibitor (vaspin) is a novel adipokine that was recently identified in the obese diabetic Otsuka Long-Evans Tokushima Fatty (OLETF) rats. Vaspin levels in the abdominal fat of OLETF

\section{KARGER}

Fax +497614520714

Information@Karger.de

www.karger.com
(C) 2011 S. Karger GmbH, Freiburg

$1662-4025 / 11 / 0042-0145 \$ 38.00 / 0$

Accessible online at:

www.karger.com/ofa
Konstantinos Tziomalos, MD, PhD

First Propedeutic Department of Internal Medicine, AHEPA Hospital

1 Stilponos Kyriakidi street, 546 36, Thessaloniki, Greece

Tel. +30 2310-994621, Fax -274434

ktziomalos@yahoo.com 
Table 1. Definition of the 3 study groups ${ }^{\mathrm{a}}$

\begin{tabular}{lllll}
\hline PCOS phenotype & ANOV & HA & PCO & Definition \\
\hline Group I* & & & & \\
1 & + & + & + & severe PCOS \\
2 & + & + & - & ANOV and HA \\
Group II & & & & \\
3 & - & + & + & ovulatory PCOS \\
4 & + & - & + & mild PCOS \\
Controls & - & - & - & \\
\hline
\end{tabular}

$\mathrm{ANOV}=$ Anovulation $; \mathrm{HA}=$ hyperandrogenemia $; \mathrm{PCO}=$ polycystic ovaries in transvaginal ultrasonography.

${ }^{\mathrm{a}}$ Definition of the 3 study groups ( $\mathrm{n}=100$ in each PCOS group and $\mathrm{n}=50$ in controls) is based on the 2003 Rotterdam criteria [1,2] for the diagnosis of polycystic ovary syndrome (PCOS).

*Also classified as PCOS before 2003 according to the National Institutes of Health criteria [5].

rats are highest at 30 weeks; serum insulin levels are also highest at the same time period. However, vaspin levels decline at 50 weeks of age, when these rats become diabetic. Vaspin was also shown to improve glucose tolerance and insulin sensitivity in mice that develop obesity, hyperinsulinemia and hyperglycemia when fed a high-fat, high-sucrose diet [10]. Recent studies in humans showed a positive correlation between the expression of the vaspin gene in the abdominal fat with circulating vaspin levels, obesity and type 2 diabetes mellitus (T2DM) $[11,12]$. The opposite change in vaspin levels when OLETF rats and humans become diabetic (decline and increase, respectively) [10-12] suggest that the regulation and actions of vaspin differ across species.

Given that many patients with PCOS have insulin resistance, obesity (usually of the central type), glucose intolerance as well as T2DM and all these conditions are associated with abnormalities in vaspin production, the present study was designed to assess i) serum vaspin levels in women with PCOS, ii) the hypothesis that the severity of PCOS is reflected upon vaspin levels and iii) the possible correlations between serum vaspin levels and the hormonal, metabolic and ultrasonographic features of PCOS. As far as we know, this is the first study that assessed serum vaspin levels in PCOS phenotypes defined according to the 1990 criteria (phenotypes 1 and 2, table 1) and the 'new' phenotypes introduced by the 2003 criteria (phenotypes 3 and 4 , table 1) [1,2].

\section{Patients and Methods}

Patients and Controls

We studied 200 patients with PCOS, 100 belonging to the phenotypes 1 and 2 (age $23.8 \pm 4.9$ years, BMI $27.4 \pm 6.7 \mathrm{~kg} / \mathrm{m}^{2}$ ) and 100 belonging to the phenotypes 3 and 4 (age $25.3 \pm 5.6$ years, BMI $26.6 \pm 6.1 \mathrm{~kg} / \mathrm{m}^{2}$ ). We also studied 50 healthy women (age $32.6 \pm 4.7$ years, BMI $25.1 \pm 4.0$ $\left.\mathrm{kg} / \mathrm{m}^{2}\right)$ with normal ovulating cycles $(28 \pm 2$ days, blood progesterone levels $>10 \mathrm{ng} / \mathrm{ml}$ in 2 consecutive cycles), no signs of HA, and normal sonographic appearance of the ovaries (controls). All women with PCOS were outpatients at the Gynecological Endocrinology Infirmary of the Second Department of Obstetrics and Gynecology, Aristotle University of Thessaloniki. Women of the control group were healthy volunteers.

Diagnosis of PCOS was based on the revised criteria of Rotterdam [1, 2] (see study protocol). None of the women studied had galactorrhea or any endocrine or systemic disease that could possibly affect reproductive physiology. A Synachten test was performed with tetracosactide (Synachten $0.25 \mathrm{mg} / \mathrm{ml}$; Novartis Pharma, Rueil-Malmaison, France) in each woman with a basal $17 \alpha$-hydroxyprogesterone $(17 \alpha-\mathrm{OHP})$ plasma level > $1.5 \mathrm{ng} / \mathrm{ml}$ to exclude congenital adrenal hyperplasia.

No woman reported use of any medication that could interfere with the normal function of the hypothalamic-pituitary-gonadal axis during the last semester. Informed consent was obtained from all women, and the study was approved by the Institutional Review Board; the study met the requirements of the 1975 Helsinki guidelines [13].

\section{Study Protocol}

In all women, weight, height, and waist circumference (WC) were measured. Body weight was measured with analogue scales and in light clothing; height was measured barefoot with a stadiometer. BMI $\left(\mathrm{kg} / \mathrm{m}^{2}\right)$ was calculated by dividing weight (in $\mathrm{kg}$ ) by height squared (in $\mathrm{m}$ ) to assess obesity. WC was obtained as the smallest circumference at the level of the umbilicus.

Baseline blood samples were collected between days 3 and 7 of the menstrual cycle in the control group and after a spontaneous bleeding episode in the PCOS group, after an overnight fast. The circulating levels of follicle-stimulating hormone (FSH), luteinizing hormone ( $\mathrm{LH})$, prolactin $(\mathrm{PRL})$, total testosterone, $\Delta_{4}$-androstenedione $\left(\Delta_{4}-\mathrm{A}\right)$, dehydroepiandrosterone-sulfate (DHEA-S), 17 $\alpha$-OHP, sex hormone-binding globulin (SHBG), glucose, insulin, thyroid stimulating hormone (TSH) and free thyroxin (FT4) were measured. Immediately after baseline blood sampling an oral glucose tolerance test (OGTT) was performed; $75 \mathrm{~g}$ of glucose were administered orally, and serum glucose levels were determined after 30, 60, 90 and $120 \mathrm{~min}$. At the same day transvaginal ultrasonography was performed and the volume of each ovary as well as the number of follicles in each ovary were determined.

Patients with PCOS were divided in two groups. The first group (group I) included 100 patients who were diagnosed with PCOS according to the 1990 criteria (phenotypes 1 and 2, table 1) [5]. These patients had oligo- or amenorrhea ( $<6$ spontaneous hemorrhagic episodes/year), biochemical hyperandrogenemia (early follicular phase testosterone $>60$ $\mathrm{ng} / \mathrm{dl}$, corresponding to the mean $\pm 2 \mathrm{SD}$ of 200 control subjects measured in our laboratory), and normal sonographic appearance of the ovaries (phenotype 2, table 1 ) or polycystic ovaries ( $\geq 12$ small follicles in at least 1 ovary and/or ovarian volume $>10 \mathrm{~cm}^{3}$ ) on ultrasound ('severe PCOS', phenotype 1, table 1). The second group (group II) included 100 patients with the additional PCOS phenotypes introduced by the 2003 criteria (phenotypes 3 and 4, table 1) [1, 2]. These patients had either HA and polycystic ovaries without oligo- or amenorrhea ('ovulatory' PCOS, phenotype 3 , table 1 ) or had oligo- or amenorrhea and polycystic ovaries without HA ('mild' PCOS, phenotype 4, table 1).

\section{Methods}

Plasma glucose, insulin, LH, FSH, PRL, androgen, $17 \alpha-\mathrm{OHP}, \mathrm{SHBG}$, TSH and FT4 concentrations were measured as previously described [4]. Serum vaspin levels were determined with an enzyme-linked immunosorbent assay (Human Vaspin Elisa kit, Antigenix America Inc., Huntington Station, NY, USA) [14]. Lower levels of detection were $<0.2 \mathrm{ng} / \mathrm{ml}$, the intra-assay coefficients of variation for low and high levels were 1.7 and $5.4 \%$, respectively, and the inter-assay coefficients of variation for low and high vaspin levels were 2.5 and $6.15 \%$, respectively. Free androgen index (FAI) was determined as follows: FAI $=\mathrm{T}(\mathrm{nmol} / \mathrm{l}) \times 100 /$ SHBG (nmol/l) [15]. The homeostasis model assessment of insulin resistance (HOMA-IR) index was calculated as follows: HOMA-IR = fasting 
Table 2. Characteristics of the study population (data are presented as mean \pm SD)

\begin{tabular}{|c|c|c|c|c|c|c|c|}
\hline & \multicolumn{2}{|l|}{ Patients with PCOS } & \multirow[t]{2}{*}{ Controls $(n=50)$} & \multirow[t]{2}{*}{$\mathrm{p}$ (overall) } & \multicolumn{3}{|c|}{$\mathrm{p}$ (for pairwise comparisons) } \\
\hline & $\begin{array}{l}\text { group I } \\
\text { (phenotypes } 1 \text { and } 2) \\
(\mathrm{n}=100)\end{array}$ & $\begin{array}{l}\text { group II } \\
\text { (phenotypes } 3 \text { and } 4) \\
(n=100)\end{array}$ & & & $\begin{array}{l}\text { group I vs. } \\
\text { controls }\end{array}$ & $\begin{array}{l}\text { group II vs. } \\
\text { controls }\end{array}$ & $\begin{array}{l}\text { group I vs. } \\
\text { group II }\end{array}$ \\
\hline Age, years & $23.8 \pm 4.9$ & $25.3 \pm 5.6$ & $32.6 \pm 4.7$ & $<0.001$ & $<0.001$ & $<0.001$ & 0.042 \\
\hline BMI, $\mathrm{kg} / \mathrm{m}^{2}$ & $27.4 \pm 6.7$ & $26.6 \pm 6.1$ & $25.1 \pm 4.0$ & NS & NA & NA & NA \\
\hline Waist, cm & $85.1 \pm 16.7$ & $81.9 \pm 12.7$ & $80.8 \pm 10.1$ & NS & NA & NA & NA \\
\hline $\mathrm{W} / \mathrm{H}$ & $0.79 \pm 0.09$ & $0.77 \pm 0.06$ & $0.78 \pm 0.06$ & NS & NA & NA & NA \\
\hline $\mathrm{FSH}, \mathrm{mIU} / \mathrm{ml}$ & $6.1 \pm 1.7$ & $6.6 \pm 1.9$ & $7.9 \pm 2.8$ & $<0.001$ & $<0.001$ & 0.012 & NS \\
\hline $\mathrm{LH}, \mathrm{mIU} / \mathrm{ml}$ & $8.3 \pm 5.4$ & $6.9 \pm 4.6$ & $5.9 \pm 2.8$ & 0.008 & 0.004 & NS & 0.016 \\
\hline Prolactin, ng/ml & $14.9 \pm 6.8$ & $13.7 \pm 7.2$ & $12.2 \pm 4.3$ & NS & NA & NA & NA \\
\hline Testosterone, ng/dl & $87.1 \pm 23.9$ & $63.0 \pm 30.9$ & $32.9 \pm 14.4$ & $<0.001$ & $<0.001$ & $<0.001$ & $<0.001$ \\
\hline$\Delta_{4}-\mathrm{A}, \mathrm{ng} / \mathrm{ml}$ & $3.2 \pm 1.0$ & $2.6 \pm 0.9$ & $1.7 \pm 0.5$ & $<0.001$ & $<0.001$ & $<0.001$ & $<0.001$ \\
\hline DHEA-S, ng/ml & $3,488.3 \pm 1,239.3$ & $2,719.8 \pm 1251.9$ & $1,944.6 \pm 811.8$ & $<0.001$ & $<0.001$ & $<0.001$ & $<0.001$ \\
\hline FAI & $9.51 \pm 6.91$ & $5.76 \pm 4.59$ & $1.98 \pm 1.16$ & $<0.001$ & $<0.001$ & 0.019 & $<0.001$ \\
\hline $17 \alpha-\mathrm{OHP}, \mathrm{ng} / \mathrm{ml}$ & $1.1 \pm 0.5$ & $1.1 \pm 0.5$ & $0.7 \pm 0.3$ & $<0.001$ & $<0.001$ & $<0.001$ & NS \\
\hline $\mathrm{SHBG}, \mathrm{nmol} / \mathrm{ml}$ & $43.1 \pm 24.9$ & $51.1 \pm 30.6$ & $69.2 \pm 33.7$ & $<0.001$ & $<0.001$ & $<0.001$ & 0.031 \\
\hline Glucose, mg/dl & $99.6 \pm 28.3$ & $97.3 \pm 11.2$ & $97.0 \pm 9.8$ & NS & NA & NA & NA \\
\hline Insulin, $\mu \mathrm{IU} / \mathrm{ml}$ & $13.1 \pm 9.1$ & $11.6 \pm 9.1$ & $9.2 \pm 6.8$ & 0.008 & 0.003 & NS & NS \\
\hline Glucose/insulin & $10.60 \pm 6.08$ & $12.44 \pm 7.13$ & $14.86 \pm 9.03$ & 0.006 & 0.002 & 0.019 & NS \\
\hline AUC OGTT & $15,355.8 \pm 2,978.7$ & $14,934.1 \pm 3,282.1$ & $14,565.6 \pm 3,352.5$ & NS & NA & NA & NA \\
\hline HOMA-IR & $3.53 \pm 4.74$ & $2.91 \pm 2.79$ & $2.24 \pm 1.71$ & 0.022 & 0.008 & NS & NS \\
\hline QUICKI & $0.33 \pm 0.03$ & $0.34 \pm 0.03$ & $0.35 \pm 0.03$ & 0.022 & 0.008 & NS & NS \\
\hline Mean ovarian volume, $\mathrm{cm}^{3}$ & $8.1 \pm 4.0$ & $11.6 \pm 5.0$ & $5.3 \pm 1.8$ & $<0.001$ & $<0.001$ & $<0.001$ & $<0.001$ \\
\hline $\begin{array}{l}\text { Mean number of ovarian } \\
\text { follicles }\end{array}$ & $10.3 \pm 5.3$ & $11.4 \pm 3.8$ & $6.2 \pm 1.9$ & $<0.001$ & $<0.001$ & $<0.001$ & 0.010 \\
\hline Vaspin, ng/ml & $2.28 \pm 2.65$ & $1.86 \pm 2.75$ & $0.57 \pm 0.72$ & $<0.001$ & $<0.001$ & 0.001 & 0.045 \\
\hline
\end{tabular}

$\mathrm{NS}=$ not significant; NA = not applicable; W/H = waist to hip ratio; FSH = follicle stimulating hormone; $\mathrm{LH}=$ luteinizing hormone;

$\Delta_{4}$-A $=\Delta_{4}$-androstenedione; DHEA-S = dehydroepiandrosterone sulfate; FAI = free androgen index; $17 \alpha$-OHP = $17 \alpha$-hydroxyprogesterone;

SHBG = sex hormone-binding globulin; AUC OGTT = area under the oral glucose tolerance test curve; HOMA-IR = homeostasis model assessment of insulin resistance; QUICKI = quantitative insulin sensitivity check index.

insulin $(\mu \mathrm{IU} / \mathrm{ml}) \times$ fasting glucose $(\mathrm{mmol} / \mathrm{l}) / 22.5$ [16]. The quantitative insulin sensitivity check index (QUICKI) was calculated according to the following formula: QUICKI $=1 /\left(\log _{\text {insulin }}(\mu \mathrm{IU} / \mathrm{ml})+\log _{\text {glucose }}(\mathrm{mg} / \mathrm{dl})\right)$ [17].

\section{Transvaginal Ultrasonography}

Transvaginal ultrasound scans of the ovaries were performed by an experienced sonographer in women who participated in the study. Ovarian volume was calculated by the formula: $\mathrm{V}=(\varpi / 6) \times \mathrm{D}_{\text {length }} \times \mathrm{D}_{\text {width }} \times \mathrm{D}_{\text {thick }}$ ness, where $\mathrm{D}$ is dimension. The presence of polycystic ovaries was diagnosed by the presence of 12 or more follicles in each ovary measuring 2-9 $\mathrm{mm}$ in diameter and/or increased ovarian volume $\left(>10 \mathrm{~cm}^{3}\right)$.

\section{Statistical Analysis}

Data analysis was performed with the statistical package SPSS (version 17.0; SPSS Inc., Chicago, IL, USA). Data are reported as mean \pm SD. Because most parameters did not follow normal distribution as assessed with the Kolmogorov-Smirnov test, comparisons between groups were performed using the Kruskal-Wallis and Mann-Whitney tests for comparisons of all 3 groups and pair-wise comparisons, respectively. Independent correlations between serum vaspin levels and other parameters were assessed using stepwise linear regression analysis including parameters that were significantly correlated with vaspin levels in univariate analysis. In all cases, a p value $<0.05$ was considered significant.

\section{Results}

The anthropometric, hormonal, metabolic and ultrasonographic characteristics of the 2 groups of patients with PCOS and of controls are shown in table 2. Patients with PCOS in groups I and II were younger than controls ( $\mathrm{p}<0.001$ for both comparisons). BMI, WC, waist-to-hip $(\mathrm{W} / \mathrm{H})$ ratio, plasma PRL and glucose levels and the area under the OGTT curve did not differ between the 2 groups of patients with PCOS and controls. Plasma testosterone, $\Delta_{4}$-A and DHEA-S levels as well as the FAI, mean ovarian volume and the mean number of follicles in the ovaries were higher in the 2 groups of patients with PCOS than in controls (table 2). Plasma testosterone, $\Delta_{4}$-A and DHEA-S levels as well as the FAI were higher in group I of patients than in group II (table 2). Plasma FSH levels were lower in both groups of patients than in controls while there were no differences in plasma FSH levels between the 2 groups of patients. Plasma LH levels were higher in group I than in group II $(\mathrm{p}=0.016)$ and controls $(\mathrm{p}=0.004)$ (table 2). Plasma 17 $\alpha$-OHP levels were higher in both groups of patients than in controls but did not differ between the 2 groups of patients with PCOS (table 2). 
Plasma insulin levels and the HOMA-IR index were higher in group I than in controls but did not differ between group II and controls or between the 2 groups of patients with PCOS. The QUICKI was lower in group I than in controls but did not differ between group II and controls or between the 2 groups of patients with PCOS (table 2).

Serum vaspin levels were higher in groups I and II than in controls ( $p<0.001$ and $p=0.001$, respectively). In addition, serum vaspin levels were higher in group I than in group II ( $\mathrm{p}=0.045)$ (table 2, fig. 1). When serum vaspin levels were assessed separately in each PCOS phenotype, significant differences were observed only between phenotypes 1 and 2 $(\mathrm{p}=0.029)$ and between phenotypes 1 and $3(\mathrm{p}=0.001)$ (table 3 ). When serum vaspin levels were assessed according to each PCOS diagnostic criterion (ANOV, HA and polycystic ovaries), significant differences were observed between patients with ANOV (phenotypes 1, 2 and 4, $\mathrm{n}=150$ ) and patients without ANOV (phenotype $3, \mathrm{n}=50)(2.3 \pm 2.8$ and $1.5 \pm 2.4 \mathrm{ng} / \mathrm{ml}$, respectively; $\mathrm{p}=0.019)$. In contrast, serum vaspin levels did not differ between patients with HA (phenotypes 1,2 and $3, \mathrm{n}=150$ ) and patients without HA (phenotype $4, \mathrm{n}=50)(2.0 \pm 2.6$ and $2.2 \pm 3.0 \mathrm{ng} / \mathrm{ml}$, respectively; $\mathrm{p}=0.974$ ) or between patients with polycystic ovaries (phenotypes 1,3 and $4, \mathrm{n}=150)$ and patients without polycystic ovaries (phenotype $2, \mathrm{n}=50)(2.2 \pm 2.8$ and $1.7 \pm 2.4 \mathrm{ng} / \mathrm{ml}$, respectively; $\mathrm{p}=0.528$ ).

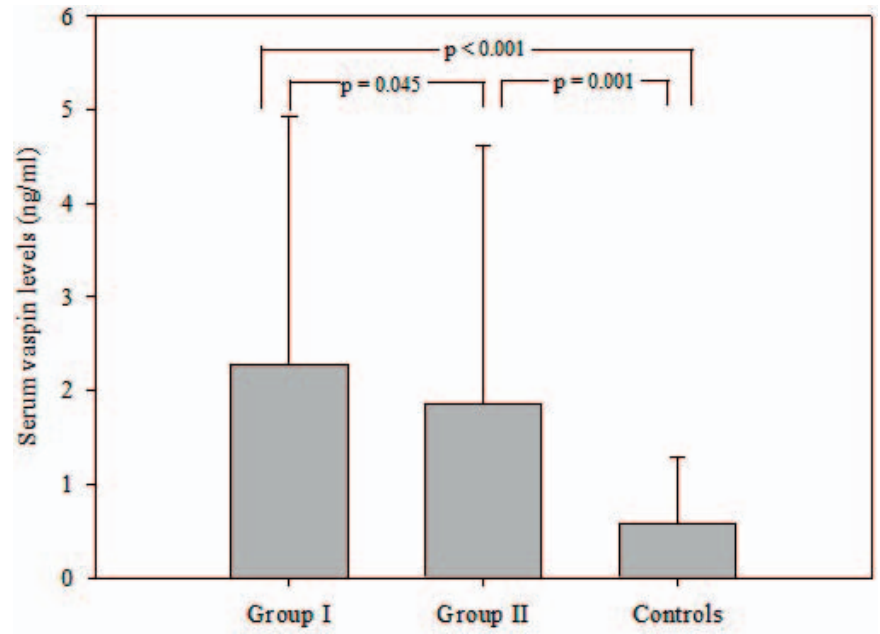

Fig. 1. Serum vaspin levels in patients with polycystic ovary syndrome (group $1=$ phenotypes 1 and 2 , group 2 = phenotypes 3 and 4 ) and controls.
Correlations between serum vaspin levels and other parameters in the total study population, in patients with PCOS and in controls are shown in table 4. In stepwise linear regression analysis, serum vaspin levels were independently correlated with BMI $(\mathrm{p}<0.001)$ and HOMA-IR $(\mathrm{p}<0.001)$ in the total study population $(\mathrm{n}=250)$. In women with PCOS $(n=200)$, serum vaspin levels were independently correlated

Table 4. Correlations between serum vaspin levels and other parameters in the total study population, in patients with PCOS and in controls

\begin{tabular}{|c|c|c|}
\hline & $\mathrm{r}$ & $\mathrm{p}$ \\
\hline \multicolumn{3}{|c|}{ Total study population $(n=250)$} \\
\hline BMI* & 0.434 & $<0.001$ \\
\hline Waist & 0.438 & $<0.001$ \\
\hline $\mathrm{W} / \mathrm{H}$ & 0.354 & $<0.001$ \\
\hline Testosterone & 0.172 & 0.006 \\
\hline FAI & 0.383 & $<0.001$ \\
\hline SHBG & -0.436 & $<0.001$ \\
\hline Glucose & 0.198 & 0.002 \\
\hline Insulin & 0.378 & $<0.001$ \\
\hline Glucose/insulin & -0.340 & $<0.001$ \\
\hline AUC OGTT & 0.167 & 0.008 \\
\hline HOMA-IR * & 0.374 & $<0.001$ \\
\hline QUICKI & -0.374 & $<0.001$ \\
\hline \multicolumn{3}{|c|}{ Patients with PCOS $(n=200)$} \\
\hline BMI* & 0.446 & $<0.001$ \\
\hline Waist & 0.455 & $<0.001$ \\
\hline $\mathrm{W} / \mathrm{H}$ & 0.397 & $<0.001$ \\
\hline FAI & 0.287 & $<0.001$ \\
\hline SHBG & -0.390 & $<0.001$ \\
\hline Glucose & 0.230 & 0.001 \\
\hline Insulin & 0.388 & $<0.001$ \\
\hline Glucose/insulin & -0.346 & $<0.001$ \\
\hline HOMA-IR* & 0.387 & $<0.001$ \\
\hline QUICKI & -0.387 & $<0.001$ \\
\hline \multicolumn{3}{|l|}{ Controls $(n=50)$} \\
\hline $\mathrm{BMI}$ & 0.316 & 0.026 \\
\hline Waist* & 0.429 & 0.002 \\
\hline $\mathrm{W} / \mathrm{H}$ & 0.314 & 0.026 \\
\hline
\end{tabular}

$\mathrm{W} / \mathrm{H}=$ waist-to-hip ratio; $\mathrm{FAI}=$ free androgen index;

AUC OGTT = area under the oral glucose tolerance test curve; HOMA-IR = homeostasis model assessment of insulin resistance; QUICKI = quantitative insulin sensitivity check index.

*Independent correlations with serum vaspin levels in stepwise linear regression analysis.
Table 3. Serum vaspin levels (mean \pm SD) according to PCOS phenotype ${ }^{a}$

\begin{tabular}{|c|c|c|c|c|c|}
\hline & $\begin{array}{l}\text { Phenotype } 1 \\
(\mathrm{n}=50)\end{array}$ & $\begin{array}{l}\text { Phenotype } 2 \\
(\mathrm{n}=50)\end{array}$ & $\begin{array}{l}\text { Phenotype } 3 \\
(\mathrm{n}=50)\end{array}$ & $\begin{array}{l}\text { Phenotype } 4 \\
(\mathrm{n}=50)\end{array}$ & $\begin{array}{l}\mathrm{p} \\
\text { (overall) }\end{array}$ \\
\hline Vaspin, ng/ml & $2.8 \pm 2.8^{* \dagger}$ & $1.7 \pm 2.4 *$ & $1.5 \pm 2.4^{\dagger}$ & $2.2 \pm 3.0$ & 0.012 \\
\hline
\end{tabular}


with BMI $(\mathrm{p}<0.001)$ and HOMA-IR $(\mathrm{p}=0.002)$. In controls $(\mathrm{n}=50)$, serum vaspin levels were independently correlated with WC $(p=0.013)$.

\section{Discussion}

Vaspin, a novel adipokine isolated from visceral white adipose tissue of OLETF rats in 2005 , is a $45.2 \mathrm{kDa}$ protein [10] that is also present in the serum [18]. Vaspin is a member of the superfamily of serpins (serine proteinase inhibitors) [19, 20]. The gene that encodes for vaspin is termed OL-64 and is present at the long arm of chromosome 14 (14q32.1) [21]. The cDNA consists of 1,245 bases and encodes for 415 amino acids [10].

In the present study, serum vaspin levels were higher in groups I and II than in controls $(\mathrm{p}<0.001$ and $\mathrm{p}=0.001$, respectively) (table 2). There are only three studies that assessed vaspin levels in patients with PCOS, yielding conflicting results [22-24]. Tan et al. [22] evaluated 12 patients with PCOS and 12 controls; serum vaspin levels were higher in patients with PCOS $(\mathrm{p}<0.05)$. Escobar-Morreale et al. [23] measured serum vaspin levels in a larger sample of patients with PCOS and in obese patients without hyperandrogenemia ( $\mathrm{n}=42$ in both groups). PCOS, obesity and impaired glucose tolerance did not affect serum vaspin levels. Finally, Cakal et al. [24] determined serum vaspin levels in 24 patients with PCOS, in 23 women with polycystic ovaries and in 24 controls. Patients with PCOS or polycystic ovaries had higher serum vaspin levels than controls. Our results, in a large number of patients with PCOS $(n=200)$ and controls $(\mathrm{n}=50)$, are in accordance with those of Tan et al. [22] and Cakal et al. [24].

Our study also showed that group I, diagnosed according to the 1990 criteria [5], had higher serum vaspin levels ( $\mathrm{p}=$ 0.045) than group II, diagnosed according to the additional criteria introduced in 2003 [1, 2]. As far as we know, there is no other study that assessed serum vaspin levels in patients with PCOS according to their phenotype. Therefore, it appears that patients with PCOS who manifest anovulation and hyperandrogenemia with or without polycystic ovaries (i.e. National Institutes of Health-defined 'classic' PCOS) have higher serum vaspin levels than both ovulatory women with polycystic ovaries and hyperandrogenemia and anovulatory women with polycystic ovaries but normal androgen levels. The elevated serum vaspin levels in patients with PCOS diagnosed according to the 1990 criteria [5], compared with levels in patients diagnosed according to the additional criteria introduced in 2003 [1, 2], suggest that circulating levels of this adipokine reflect the severity of the syndrome regarding its metabolic features, traditionally defined by its two cardinal elements, i.e. ANOV and HA (table 2, fig. 1) [25-28].

In the present study, even though fasting insulin levels and the HOMA-IR index were higher and the QUICKI lower in group I than in controls $(\mathrm{p}=0.003, \mathrm{p}=0.008$ and $\mathrm{p}=0.008$, respectively), these parameters did not differ between group II and controls (table 2). It has been reported that obesity and IR increase vaspin expression in abdominal fat as well as its concentration in the serum $[11,12]$. The increase in vaspin levels might represent a compensatory response against the obesity and IR-stimulated production of yet-to-be-identified proteases. The former proteases are synthesized in the abdominal fat but also in other tissues and appear to suppress the action of insulin. Therefore, the induction of vaspin expression might represent a defense mechanism against IR. In animal models, administration of recombinant vaspin suppressed the expression of IR-promoting adipokines (including resistin, tumor necrosis factor- $\alpha$ and leptin) and stimulated the synthesis of insulin-sensitizing adipokines (e.g. adiponectin and glucose transporter 4) [10]. These findings support the notion that vaspin down-regulates the expression of genes associated with IR and that this action is more prominent in the abdominal fat [10].

It is of interest that serum vaspin levels are elevated in patients with PCOS (i.e. a condition with a high prevalence of IR, glucose intolerance and T2DM), given the recent observation by Youn et al. [12] that insulin-resistant, obese patients also have increased serum vaspin levels. In the this study [12], a significant correlation between serum vaspin levels and BMI was observed. In the present study, in all patients with PCOS $(n=200)$, serum vaspin levels were independently correlated with BMI and the HOMA-IR index $(\mathrm{p}<0.001$ and $\mathrm{p}=0.002$, respectively). Moreover, our study suggests that vaspin does not play an important role in HA characteristic of PCOS. Indeed, serum vaspin levels did not differ between phenotype 4 (which lacks HA) and the other 3 phenotypes (characterized by HA) (table 3 ). In addition, even though serum vaspin levels correlated with FAI in patients with PCOS in univariate analysis, this correlation did not persist in stepwise linear regression analysis (table 4).

In conclusion, our findings suggest that PCOS and obesity are associated with elevated serum vaspin levels. The increased serum vaspin levels in patients with PCOS and particularly in overweight or obese women might represent a compensatory mechanism to preserve insulin sensitivity and glucose tolerance. Moreover, serum vaspin levels reflect the severity of PCOS and are significantly increased in its "classical' phenotypic forms, defined by the 1990 criteria, as opposed to the recently introduced PCOS subtypes. This increase in serum vaspin levels in the 'classical' PCOS phenotypes might be attributed to the more adverse metabolic profile of these patients, including greater total and abdominal obesity, IR, and risk factors for cardiovascular disease and T2DM.

\section{Disclosure Statement}

We have no conflict of interest to declare. 


\section{References}

1 Rotterdam ESHRE/ASRM-Sponsored PCOS Consensus Workshop Group: Revised 2003 consensus on diagnostic criteria and long-term health risks related to polycystic ovary syndrome (PCOS). Hum Reprod 2004;19:41-47.

2 Rotterdam ESHRE/ASRM-Sponsored PCOS Consensus Workshop Group: Revised 2003 consensus on diagnostic criteria and long-term health risks related to polycystic ovary syndrome. Fertil Steril 2004;81:19-25.

3 Diamanti-Kandarakis E, Panidis D: Unravelling the phenotypic map of polycystic ovary syndrome (PCOS): a prospective study of 634 women with PCOS. Clin Endocrinol 2007;67:735-742.

4 Norman RJ, Dewailly D, Legro RS, Hickey TE: Polycystic ovary syndrome. Lancet 2007;370:685697.

5 Zawadski JK, Dunaif A: Diagnostic criteria for polycystic ovary syndrome: towards a rational approach; in Dunaif A, Givens JR, Haseltine FP, Merriam GE, Hershman SM (eds): Polycystic Ovary Syndrome. Current Issues in Endocrinology and Metabolism. Boston, Blackwell, 1992, pp 377-384.

6 Azziz R, Ehrmann D, Legro RS, Whitcomb RW, Hanley R, Fereshetian AG, O'Keefe M, Ghazzi MN; PCOS/Troglitazone Study Group: Troglitazone improves ovulation and hirsutism in the polycystic ovary syndrome: a multicenter, double blind, placebo-controlled trial. J Clin Endocrinol Metab 2001;86:1626-1632.

7 Legato MJ: Gender-specific aspects of obesity. In J Fertil Womens Med 1997;42:184-197.

8 Björntorp P: Abdominal obesity and the metabolic syndrome. Ann Med 1992;24:465-468.

9 Dunaif A, Segal KR, Futterweit W, Dobrjansky A: Profound peripheral insulin resistance, independent of obesity, in polycystic ovary syndrome. Diabetes 1989;38:1165-1174.

10 Hida K, Wada J, Eguchi J, Zhang H, Baba M, Seida A, Hashimoto I, Okada T, Yasuhara A, Nakatsuka A, Shikata K, Hourai S, Futami J, Watanabe E, Matsuki Y, Hiramatsu R, Akagi S, Makino H, Kanwar YS: Visceral adipose tissue-derived serine protease inhibitor: a unique insulin-sensitizing adipocytokine in obesity. Proc Natl Acad Sci U S A 2005;102:10610-10615.
11 Klöting N, Berndt J, Kralisch S, Kovacs P, Fasshauer M, Schön MR, Stumvoll M, Blüher M: Vaspin gene expression in human adipose tissue: association with obesity and type 2 diabetes. Biochem Biophys Res Commun 2006;339:430-436.

12 Youn BS, Klöting N, Kratzsch J, Lee N, Park JW, Song ES, Ruschke K, Oberbach A, Fasshauer M, Stumvoll M, Blüher M: Serum vaspin concentrations in human obesity and type 2 diabetes. Diabetes 2008;57:372-377.

13 World Medical Association Declaration Of Helsinki: Ethical Principles for Medical Research Involving Human Subjects www.wma.net/en/ 30publications/10policies/b3/17c.pdf (accessed 27/ 12/2010).

14 Antigenix America Inc: Human Vaspin 'Super-X' Pre-Coated ELISA Kit. www.antigenix.com/ Merchant2/datasheet/RHF501CKX.pdf (accessed 27/12/2010).

15 Carter GD, Holland SM, Alaghband-Zadeh J, Rayman G, Dorrington-Ward P, Wise PH: Investigation of hirsutism: testosterone is not enough. Ann Clin Biochem 1983;20:262-263.

16 Matthews D, Hosker J, Rudenski A, Naylor B, Treacher D, Turner R: Homeostasis model assessment: insulin resistance and beta-cell function from fasting plasma glucose and insulin concentrations in man. Diabetologia 1985;28:12-19.

17 Katz A, Nambi SS, Mather K, Baron AD, Follmann DA, Sullivan G, Quon MJ: Quantitative insulin sensitivity check index: a simple, accurate method for assessing insulin sensitivity in humans. J Clin Endocrinol Metab 2000;85:2402-2410.

18 Carrell R, Travis J: $\alpha 1$-Antitrypsin and the serpins: variation and countervariation. Trends Bioch Sci 1985;10:20-24.

19 Gettins PG: Serpin structure, mechanism, and function. Chem Rev 2002;102:4751-4804.

20 Baxter EW, Cummings WJ, Fournier REK: Formation of a large, complex domain of histone hyperacetylation at human $14 \mathrm{q} 32.1$ requires the serpin locus control region. Nucleic Acids Res 2005; 33:3313-3322.
21 Hida K, Wada J, Zhang H, Hiragushi K, Tsuchiyama Y, Shikata K, Makino H: Identification of genes specifically expressed in the accumulated visceral adipose tissue of OLETF rats. J Lipid Res 2000;41:1615-1622.

22 Tan BK, Heutling D, Chen J, Farhatullah S, Adya R, Keay SD, Kennedy CR, Lehnert H, Randeva HS: Metformin decreases the adipokine vaspin in overweight women with polycystic ovary syndrome concomitant with improvement in insulin sensitivity and a decrease in insulin resistance. Diabetes 2008;57:1501-1507.

23 Escobar-Morreale HF, Luque-Ramirez M, SanMillan JL: Serum visceral adipose tissue-derived serine protease inhibitor concentrations in human obesity and polycystic ovary syndrome. Diabetes Care 2009;32:e6.

24 Cakal E, Ustun Y, Engin-Ustun Y, Ozkaya M, Kilinc M: Serum vaspin and C-reactive protein levels in women with polycystic ovaries and polycystic ovary syndrome. Gynecol Endocrinol 2010; doi:10. 3109/09513590.2010.501874

25 Moran L, Teede H: Metabolic features of the reproductive phenotypes of polycystic ovary syndrome. Hum Reprod Update 2009;15:477-488.

26 Jovanovic VP, Carmina E, Lobo RA: Not all women diagnosed with PCOS share the same cardiovascular risk profiles. Fertil Steril 2010;94:826-832.

27 Svendsen PF, Madsbad S, Nilas L: The insulinresistant phenotype of polycystic ovary syndrome. Fertil Steril 2010;94:1052-1058.

28 Wild RA, Carmina E, Diamanti-Kandarakis E, Dokras A, Escobar-Morreale HF, Futterweit W, Lobo R, Norman RJ, Talbott E, Dumesic DA: Assessment of cardiovascular risk and prevention of cardiovascular disease in women with the polycystic ovary syndrome: a consensus statement by the Androgen Excess and Polycystic Ovary Syndrome (AE-PCOS) Society. J Clin Endocrinol Metab 2010;95:2038-2049. 